\title{
СОЦИАЛЬНАЯ ИНТЕГРАЦИЯ ИНОСТРАННЫХ СТУДЕНТОВ С ОГРАНИЧЕННЫМИ ВОЗМОЖНОСТЯМИ
}

\author{
() 2020 Сидорова Анна Викторовна \\ старший преподаватель кафедры публичного права \\ Самарский государственный экономический университет, Россия, Самара \\ E-mail:an.sido@bk.ru \\ (c) 2020 Ефремова Елена Александровна \\ доцент кафедры международного права и политологии \\ Самарский государственный экономический университет, Россия, Самара \\ E-mail: lenoksamara97@gmail.com
}

В статье рассматриваются проблемные аспекты социальной интеграции иностранных студентов. Проводится анализ статистических данных российских и зарубежных учебных учреждений. Исследование направлено на привлечение внимания к проблемным моментам в вопросах увеличения числа иностранных студентов и в особенности студентов-иностранцев с ограниченными возможностями для получения высшего образования в России, обоснованности актуализации, конкретизации и систематизации методических и методологических разработок процесса интегрированного обучения студентов с ограниченными возможностями из числа иностранных студентов.

Ключевые слова: интеграция, инклюзия, инвалидность, иностранные студенты, личность, образовательная среда, социокультурные особенности.

В современной науке процесс социализации определяется как процесс усвоения социальных стандартов поведения, ценностных ориентаций, гармонизации взаимосвязей с новой средой и активного воспроизводства приобретенного социального опыта в собственной деятельности и общении. Социализация личности выступает достаточно противоречивым и многоплановым процессом взаимодействия индивида и общества. Общеизвестно, что личность - это человеческая индивидуальность, которая выступает как субъект познания и преобразования мира. Одним из условий социализации индивида является процесс его интеграции в общество. Под интеграцией в научной среде принято понимать предоставление человеку с особыми потребностями прав и возможностей для субъективизации его во всех областях социальной жизни наравне с иными членами общества. В современных российских социально-педагогических исследованиях интеграция определяется как: «во-первых, процесс и состояние сочетание различных по качеству социальных элементов в функционально единый организм, во-вторых, это процесс вхождения в определенную систему (целостности), которая уже образовалась, в той или иной социальной доли (группы, индивида), что сливается с системой и приобретает призна- ки структурного, составляющего элемента» [2]. Отдельно хотелось бы остановиться на вопросе привлечения к обучению в российских ВУЗах иностранных студентов. В этой связи следует отметить, что иностранные студенты могут стать ключевым источником финансирования российских высших учебных заведений, тем самым внося значительный вклад в экономику страны за счет платы за обучение, расходов на проживание и связанных с этим расходов, например, таких как визиты родителей в Россию. Так, например по статистике в 2014-2015 гг. доход бюджета Великобритании от платы за обучение только от студентов из стран не входящих в ЕС составил 4,2 миллиарда фунтов стерлингов [11]. По данным Higher Education Policy Institute (HEPI) и Kaplan International Pathways (Kaplan) в стране доля иностранных от общего числа студентов составляет $19,7 \%$ [14]. Надо признать, что сумма внушительная. В Атлантической Канаде на сегодняшний день в университетах обучается более 25000 иностранных студентов. По мнению канадских аналитиков именно они удерживают университеты на плаву по мере того, как число учащихся в стране с каждым годом резко падает. Кроме всего прочего, именно студенты-иностранцы являются основной частью региональной экономики и основным источником иммиграции, 
необходимой для противодействия быстрому старению населения региона [15]. Согласно исследованиям, опубликованным в 2019 г, иностранные студенты вносят 795 миллионов долларов в год в экономику Атлантической Канады и ежегодно вносят 22 млн. долларов в виде налогов. В 2018 году в Канаде обучалось 721000 иностранных студентов, пополнивших ВВП страны на 21,6 млрд. долл. [10]. С 2014 по 2018 годы их количество увеличилось на 68\%. Привлечение иностранных студентов важная тема и для Министерства образования и профессиональной подготовки Австралии. Ежегодно австралийские университеты отчитываются перед Министерством о поступающих и особый интерес представляют данные о доле иностранных студентов, доли доходов, получаемых от них. Так, согласно данных в 2014 г. иностранные студенты составляли 24,3\% от общего количества обучающихся в австралийских высших учебных заведениях, а в 2019 г. уже 26,7\% [16]. В 2018 г. международные студенты пополнили бюджет страны в размере 31,9 млрд. долл. [17].

Следует сказать, что количество иностранных обучающихся является одним из критериев включения учебного заведения в мировой рейтинг ВУЗов. Общеизвестно, что рейтинг университетов мира складывается из суммы баллов, выставляемых образовательному заведению по конкретизированным параметрам и критериям. Исходя из этих цифр формируется список топовых ВУЗов. Место, занимаемое образовательным заведением, учитывается большинством авторитетных работодателей при конкурсном отборе кандидатов на должности в организации. Так, например, третьим из двенадцати факторов, обосновывающих место образовательной организации в рейтинге по Британским критериям оценивания, является число иностранных студентов, получающих образование в данной организации. Данный критерий более весом даже чем такие критерии как: публикационная активность преподавательского состава; процентный состав остепененных преподавателей; рейтинг ВУЗа в академической среде и которые расположены ниже по списку критериев. Такой же критерий учитывается и при составления рейтинга лучших мировых образовательных учреждений по версии Times Higher Education (THE World University Rankings) [5].

Тема привлечения иностранных студентов была затронута и Президентом РФ в ежегод- ном послании Федеральному Собранию РФ. Он отметил важность привлечения иностранных студентов в российские ВУЗы для обучения с последующим трудоустройством талантливейших из них и упрощению получения такими лицами российского гражданства. В этой связи хотелось бы вспомнить и слова нашего Президента, указавшего еще в 2016 г. на необходимость создания государственной организации, которая занималась бы интеграцией и адаптацией приезжих из других стран в Россию [12]. Согласно статистических данных процентное соотношение иностранных студентов от общего числа студентов сильно варьируется в различных странах, так в России их 4,1\%, в Великобритании - 18,1\%, в США - 5\%, в Японии - 3, 7\% [7]. На сегодняшний день в ВУЗах страны обучается 297,9 тысячи иностранных граждан. В планах Министерства образования и науки довести эту цифру к 2025 году до 760 тысяч [8]. В подавляющем большинстве это граждане бывших республик СССР. Российские высшие учебные заведения привлекают студентов из зарубежных стран соотношением «цена-качество». Однако существует и много проблемных моментов: языковые проблемы, жесткие миграционные правила, отсутствие комфортабельного жилья. Все эти проблемы сохраняют свою актуальность и в отношении иностранных студентов с ограниченные возможностями и усугубляются рядом специфических для данной группы проблем.

Говоря о социальной интеграции иностранных студентов с ограниченными возможностями, следует отметить, что данный процесс содержит в себе ряд ключевых препятствий. Воспринимаемое студентами-иностранцами временное пребывание в условиях новой культуры в стране обучения достаточно часто приводит к минимизации контактов с коренным населением, превалированию общения с земляками и предпочтению поддержке тесных контактов с родной культурой (путем частых поездок домой и / или ограничением межличностного взаимодействия с кругом своей диаспоры) [3]. Установка на временное проживания в другой стране порождает сознательное или неосознаваемое уклонение от необходимости адаптироваться к новым социокультурным условиям, что осложняет и замедляет процесс межкультурной адаптации студентов-иностранцев, углубляет и пролонгирует переживание культурного шока, вызывает деформации этнической идентично- 
сти, препятствует развитию этнонациональной толерантности. Наконец, такое уклонение от необходимости адаптации к новой культуре является одним из важнейших препятствий успешного получения высшего профессионального образования, которое является ведущей целью пребывания студента-иностранца в стране обучения. Еще одной сложностью социальной интеграции становится инвалидность студента. Предоставление образования инвалидам ставит перед ВУЗами определенные задачи по обеспечению надлежащего методического уровня организации учебного процесса, специфического сопровождения обучения и создания необходимых условий для быта. К сожалению, приходится признать, что в отечественных учебных заведениях еще не созданы достаточные условия для людей с особыми потребностями. Основной трудностью для их создания является недостаточное материально-техническое обеспечение, небольшое количество специалистов, имеющих опыт работы с инвалидами, психологическая неготовность преподавателей работать со студентами-инвалидами.

Сегодня идеи интегрированного обучения людей с ограниченными возможностями все больше проникают в наше общество. Под интеграцией понимается привлечение инвалидов в общество в качестве полноправных его членов, принимающих активное участие во всех сферах жизнедеятельности, освоение ими экономики, культуры, науки [9]. Интеграция обучающихся представляет собой процесс совместного обучения студентов с ограниченными возможностями и студентов, не относящихся к данной категории. Именно такая форма обучения реализует равное право на получение образования за людьми с ограниченными возможностями, что обосновывает необходимость в разработке и осуществлении политики равных возможностей обучения и воспитания студентов с инвалидностью, осуществляемой в интегрированных группах. Но для обучения ребенка или взрослого с определенными ограничениями в интегрированном учебном заведении должны быть созданы соответствующие условия и социальный, психологический и педагогический сопровождение. Адаптация студента с инвалидностью к данной микросреде среде является одной из основных задач первых студенческих лет. Студентам необходимо не просто ознакомиться с самой структурой вуза, принятой системой контроля знаний, но и успешно войти в студенческий коллектив, в ритм студенческой жизни и обучения, для того, чтобы максимально раскрыть свои таланты и способности уже во время обучения. Многочисленные аспекты адаптации и интеграции студентов с особыми потребностями в студенческую среду могут быть успешно реализованы благодаря не только их личным усилиям, но и благодаря вниманию и помощи родителей, товарищей по учебе, преподавателей и сотрудников вуза. Позитивным фактором является и то, что, когда учащиеся с ограниченными возможностями получают образование совместно со своими сверстниками без инвалидности, они получают соответствующие возрасту социальные навыки, подражая студенту-сверстнику без инвалидности в окружающей их среде. Интеграция студентов с физическими ограничениями необходима поскольку при этом студенты учатся быть более независимыми, приобретая различные социальные и бытовые навыки. Кроме того, они в процессе непосредственного общения с другими студентами развивают позитивный образ самих себя, имея возможность делать то, что и другие студенты. Хотелось бы еще сказать вот о чем. Важным в процессе интеграции, рассматриваемой нами группы студентов, являлось бы внедрение в обучающий процесс интегрированных программ (мероприятий) для студентов, а также их родителей. Участие в таких интегрированных программах, дало бы родителям детейинвалидов возможность увидеть, что поведение их детей типично для большинства студентов. Увидев, что их дети приняты другими и успешны в интегрированных программах (мероприятиях) родители смогут чувствовать себя лучше и улучшить психологический климат в семье. Родители детей с ограниченными возможностями также будут иметь возможность познакомиться с другими родителями и участвовать в тех же мероприятиях. Участие студентов без инвалидности и их родителей в таких мероприятиях даст возможность им получить положительный опыт и позволит им узнают об инвалидах больше и развивать позитивное отношение к людям с инвалидностью. Проведение таких интегративных мероприятий поможет расширять личный опыт не только детей, но и родителей и преподавательского состава.

Говоря о студентах иностранцах с инвалидностью, стоит отметить, что процессу интеграции должен предшествовать процесс инклюзии. 
При видимой схожести этих понятий, все же стоит отметить, что если в процессе интеграции проявляются субъект-субъективные отношения, взаимоадаптации, то в процессе инклюзии адаптация индивида к социуму. Так, для интеграции важным является процесс становления личности как субъекта образовательного процесса. По мнению некоторых экспертов будущее образования заключается в развитии ее инновационной составляющей, в таком русле стоит говорить уже о развитии «субъекта инноваций» [4], развитие которого становится залогом успешного образования в целом. Если для интеграции характерна двусторонняя инициация развития личности и социального прогресса, то для инклюзии условием привлечения индивида к социуму является его социальное развитию. Таким образом, индивид, социализируется, опираясь на предварительно приобретенные знания и навыки. А вот приобретение личностью каких-либо иных ценностей и норм, осуществляется как раз в условиях интеграции. В условиях инклюзии индивид адаптируется к среде с учетом накопленного знания и опыта общения и взаимодействия с другими. Можно констатировать - интеграция обеспечивает расширение зоны активности индивида за счет раскрытия его индивидуальности, инклюзия - за счет типичного опыта, обусловленного нормативным характером его приобретения. Организация интегрированного обучения иностранных студентов инвалидов в ВУЗах должна учитывать общие и специфические принципы гуманистической педагогики и психологии, важнейшими из которых являются: целенаправленное личностное развитие инвалида в процессе деятельности и общения; интенсифицирование внутренней активности личности; гармонизация гуманизма и высокой требовательности; дифференциация подходов с учетом возраста и индивидуальных особенностей; коллективное воспитание; един- ство и согласованность требований, усилий и действий вузов, семьи, общественности; законность и обеспечение прав человека; ответственность за не соблюдение правил и норм во взаимоотношениях со студентом-инвалидом; доступность; опора на потенциальные возможности человека и максимизация социальных ресурсов; сочетание помощи с самопомощью; добровольность в принятии помощи; ответственность субъектов социальной работы за сохранение этнических и правовых норм [13, 6, 1,].

Таким образом, можно сделать вывод, что необходимой чертой обучения в интегрированном коллективе, студентов с ограниченными возможностями является восприятие их как равных, и как следствие предъявление им абсолютно таких же требований, как и остальным студентам. Многим студентам с особыми потребностями в вузах не хватает достаточного внимания и поддержки со стороны преподавателей. Преподаватель ориентируется на большинство аудитории, что может привести к неуспеванию студента с инвалидностью по сравнению с большинством. Помощь в интеграции иностранного студента с инвалидностью к условиям обучения и предоставления ему поддержки могут происходить только путем организации сопровождения их обучения. Кроме того, большой положительный эффект в интеграции таких студентов, а наш взгляд привнесли бы разработка и внедрение в образовательный процесс интегративных программ (мероприятий) участниками которых были бы студенты и студенты с ограниченными способностями, а также их родители. Было бы целесообразным создать на базе Министерства науки и высшего образования отдел в полномочия которого выражались бы в разработке методических рекомендаций для привлечения иностранных студентов для обучения в российских ВУЗах.

\section{Библиографический список}

1. Ахметов С.И. Развитие личности студента посредством образовательных ресурсов Интернета в условиях инклюзивного образования: // Сборник статей участников Всероссийской научно-практической конференции с международным участием: Проблемы и перспективы дополнительного образования детей и взрослых. Арзамас, 2019. С. 17-20.

2. Вернер Н.А. Исследование отечественных и зарубежных подходов к интегрированному и инклюзивному обучению в образовательных организациях // Санкт-Петербургский образовательный вестник. 2017. № 11-12 (15-16). URL: https://cyberleninka.ru/article/n/issledovanie-otechestvennyh-i-zarubezhnyhpodhodov-k-integrirovannomu-i-inklyuzivnomu-obucheniyu-v-obrazovatelnyh-organizatsiyah (дата обращения: 18.03.2020). 
3. Гез Т.А., Старикова В. О. Иностранные студенты, мигрирующие в Россию: проблемы адаптации и способы их решения // Студенческий. 2018. № 1-1 (21). С. 67-71.

4. Гудкова Т.В. Современные пути интеграции людей с ограниченными возможностями здоровья и инвалидностью в социальную жизнь // Вестник НГПУ, 2016. № 1 (29). С.68-76.

5. Гуманитарный портал. Рейтинг лучших университетов мира по версии Times Higher Education (THE World University Rankings).URL: https://gtmarket.ru/ratings/the-world-university-rankings/info (дата обращения: 18.03.2020).

6. Лапина И.Ю., Каргапольцев С.Ю. Инклюзивное образование как гносеологическая форма гуманизма: теория и практика вопроса // Материалы VI Международной научно-практической конференции: Педагогические параллели. Санкт-Петербург, 2018. С. 499-502.

7. Образование в цифрах. Краткий статистический сборник. URL: https://www.hse.ru/ data/2019/08/12/1483728373/oc2019.PDF (дата обращения: 18.03.2020).

8. Российская газета.RG.RU. URL: https://rg.ru/2017/11/13/chislo-inostrannyh-studentov-v-rossii-vyrastet-vtroe. htm (дата обращения: 18.03.2020).

9. Шафикова М.Р. Особенности адаптации иностранных студентов: современный взгляд на проблему // сборник статей VII Международной научно-практической конференции: ADVANCED SCIENCE. Пенза, 2019. C. $226-231$.

10. Building on success: international education strategy 2019-2024. Her Majesty the Queen in Right of Canada, as represented by Global Affairs Canada, 2019.

11. Economic and Social Research Council (Shaping Society). URL: https://esrc.ukri.org/news-events-andpublications/evidence-briefings/attracting-international-students-to-the-uk/ (дата обращения: 18.03.2020).

12. Mbulak. URL: https://www.molbulak.ru/news/novosti-migratsii/v-v-putin-ob-adaptatsii-inostrannykhgrazhdan-v-rossii/ (дата обращения: 18.03.2020).

13. Tskvitariia T. The problem of students in multicultural educational space of medical university // Научный альманах стран Причерноморья. 2019. № 2 (18). С. 34-38. DOI 10.23947/2414-1143-2019-18-2-34-8.

14. The costs and benefits of international students by parliamentary constituency Report for the Higher Education Policy Institute and Kaplan International Pathways // https:/www.hepi.ac.uk/wp-content/uploads/2018/01/ Economic-benefits-of-international-students-by-constituency-Final-11-01-2018.pdf （дата обращения 18.03.2020).

15. THE CONVERSATION. URL: http://theconversation.com/the-importance-of-international-students-to-atlanticcanada-96230 (дата обращения: 18.03.2020).

16. The pie blog industry insight from professionals in international education. URL: https://blog.thepienews. com/2015/10/how-important-are-international-students-to-australias-universities/ (дата обращения 18.03.2020).

17. Universities Australia. The voice of Australia's universities. URL: www.universitiesaustralia.edu.аu (дата обращения 18.03.2020) 